\title{
Kinetic Study of Cotton Stalk and Rice Husk Samples under an Inert and Oxy Combustion Atmospheres
}

\author{
GHULAMULLAH MAILTO*†, RASOOL BUX MAHAR**, IMRAN NAZIR UNAR***, \\ AND KHAN MUHAMMAD BROHI**** \\ RECEIVED ON 14.04.2017 ACCEPTED ON 29.05.2017 \\ ABSTRACT
}

\begin{abstract}
Biomass materials such as CS (Cotton Stalks) and RH (Rice Husk) are a renewable source of energy. As biomass resources have potential to offer a uninterpted supply of biofuels through thermal decomposition processes. Nevertheless, an appropriate understanding of reaction kinetics and thermal properties of biomasses play a vital role in designing of the commercial plants using biomass as a raw material for energy generation. The kinetic characteristics of the CS and RH samples under pure nitrogen $99.9 \%$ and pure oxygen $99.9 \%$ was performed. The temperature was raised from ambient to $900^{\circ} \mathrm{C}$ maintaining the heating rate of $10^{\circ} \mathrm{C} / \mathrm{min}$. $\mathrm{CS}$ and $\mathrm{RH}$ decomposition was noticed in three dissimilar regions. The kinetic characteristics such as (pre-exponential factor, the order of reaction and activation energy) were calculated for both selected materials. The activation energies calculated under nitrogen environment for CS and RH was 68.77 and $72.31 \mathrm{~kJ} / \mathrm{mole}$, whereas the regression coefficient $\left(R^{2}\right)$ was 0.9877 and 0.9731 respectively. The activation energies under oxygen environment were higher, it was 106 and 118 $\mathrm{kJ} / \mathrm{mole}$. The regression coefficient $\left(\mathrm{R}^{2}\right)$ under oxygen environment was 0.9987 and 0.99883 for above sample sequence.
\end{abstract}

Key Words: Rice Husk, Cotton stalks, Oxygen, Thermogrammetric Analysis, Kinetic Study

\section{INTRODUCTION}

$\mathrm{F}$ bssil fuels consumption and their ever growing demand cause the increase in GHG (Greenhouse Gas) emissions [1]. The application of biomass for clean and sustainable energy in substantial quantities from agricultural residues is considered as one of the best substitute for fossil fuels worldwide. In addition, fossil fuel deposits take millions of years to accumulate, whereas, these deposits are extracted rapidly. Given that the extraction rate of fossil fuels is higher than their replenishment rate, therefore these finite resources will end up in near future [2-3]. Due to rapid depletion of fossil fuels, various governments have planned to alter their energy matrix in order to increase the share of renewable sources [4]. Owing to this fact, researchers and policy

†Corresponding Author (E-Mail: metlo2696@yahoo.com)

* Department of Chemical Engineering, Dawood University of Engineering \& Technology, Karachi.

** US-Pakistan Centres for Advance Studies in Water, Mehran University of Engineering \& Technology, Jamshoro.

*** Department of Chemical Engineering, Mehran University of Engineering \& Technology, Jamshoro.

**** Institute of Environmental Engineering \& Management, Mehran University of Engineering \& Technology, Jamshoro.

This is an open access article published by Mehran University Research Journal of Engineering and Technology, Jamshoro under the CC by 4.0 International License. 
makers aim to get energy from biomass including agricultural wastes. Agricultural residues include CS, RH, corn straw, wheat straw, and wheat husks, among these sources, CS and RH are least used resources in developing countries [5-8]. Agricultural residues such as CS, RH corn cobs, sugarcane bagasse and wheat straw are a viable source for bioenergy production. The copious quantities of agricultural wastes are underutilized resources in developing countries. These resources of renewable energy are used either as an animal feed or as a raw material for paper industry. The excessive agricultural residues are burned in the fields or left untouched as a waste material, thereby causing substantial environmental hazards. The conversion methods for biomass may be physical, chemical, biological or thermal to give a solid liquid or gaseous products. Among all conversion methods, the thermochemical conversion method seems to be one of the most promising conversion methods for bioenergy production.

Nevertheless, the development of economically and technically viable method for the conversion of the CS and $\mathrm{RH}$ residues into higher value fuels through thermochemical conversion processes involves an understanding of its thermal characteristics and reaction kinetics. The thermochemical conversion of agricultural residues is strongly influenced by their chemical composition such as cellulose, hemicellulose and lignin contents [9]. The above agricultural residues can be used to generate energy through direct combustion, which is a less efficient method of energy recovery from residues. The most efficient method to obtain energy from biomass residues is pyrolysis, as through pyrolysis process various energy products such as solid, liquid and gaseous are obtained. Hence for valid kinetic data regarding the thermochemical conversion of RH and CS, it is important to perform comprehensive TGA (Thermogravimetric Analysis) investigation on both selected materials. Therefore, in the present study, TGA techniques were applied to investigate the thermal degradation behavior and kinetic characteristics of $\mathrm{RH}$ and $\mathrm{CS}$ residues in aninert $\left(\mathrm{N}_{2}\right)$ and oxidative $\left(\mathrm{O}_{2}\right)$ atmospheres.

This analysis was carried out in order to understand the thermal degradation parameters and reaction kinetics of CS and RH samples. The aims of this study include:

To perform TGAon the CS and RH samples at the heating rates of $10^{\circ} \mathrm{C} / \mathrm{min}$ in an inert $\left(\mathrm{N}_{2}\right)$ and oxidative $\left(\mathrm{O}_{2}\right)$ environments.

To determine the initial degradation temperatures, thermal degradation rates and residual weight of $\mathrm{RH}$ and $\mathrm{CS}$ samples at $900^{\circ} \mathrm{C}$.

To estimate the kinetic constraints (such as preexponential factor, apparent activation energy and order of reaction) by means of TGA data.

\section{MATERIALS AND METHOD}

The biomasses used in this study included RH and CS from district Khairpur Mirs located in between middle and northern Sindh province, Pakistan. The CS samples were cut into small pieces in order to reduce handling problems. The RH and CS sample were suns dried for 4-5 days in order to reduce the moisture content of selected biomass samples. After drying process the samples were transported to Department of Chemical Engineering, Mehran University of Engineering \& Technology, Jamshoro, Pakistan, for size reduction. These samples were ground using a hammer mill, commonly known as beater cross mill. The revolving beater bars of hammer mill reduced the size of samples. These samples were passed through $250 \mu \mathrm{m}$ (60 mesh). After sieving of RH and CS samples were placed into an airtight plastic bags for TGA. The complete procedure used for the preparation of WAB (Waste Agricultural Biomass) samples include sun drying, hammer milling, sieving and bagging shown in an inverse pyramid in Fig. 1. 


\subsection{Chemical and Physical Analysis of Waste Agricultural Biomass}

Following analysis was done on the $\mathrm{CS}$ and $\mathrm{RH}$ samples such as TGA, CHNS (Elemental Analyses), density and calorimetric analysis. In order to investigate the chemical properties of WAB regarding the thermochemical conversion, ultimate and proximate investigation were carried out on both biomass materials. Density analysis of WAB was performed using an empty glass cylinder of $100 \mathrm{ml}$ volume. For removal of moisture available in the empty cylinder, the temperature of the oven was maintained at $110^{\circ} \mathrm{C}$. The empty cylinder was filled with water up to $100 \mathrm{ml}$ marking. After removal of moisture, a glass cylinder was placed on electronic balance for tare weight. The empty glass was filled with WAB and its mass was determined in grams. The filled volume of water was subtracted from $100 \mathrm{ml}$ that offer a net volume of sample in ml. Results of density analysis are presented in Table 1. For the measurement of calorific value, an adiabatic calorimeter was used. The analysis of bomb calorimeter data was done using formula, which is appropriate for the equipment used. The calorific value of the samples is given in Table 1.

$\mathrm{HCV}=(\mathrm{TD} \times 2000+585) / \mathrm{Ms}$

TD is a temperature difference of inner cylinder in ${ }^{\circ} \mathrm{C}$ and Ms is a mass of sample in gram.

\subsection{Elemental Analysis of Waste Agricultural Biomass}

The analysis of carbon, hydrogen, nitrogen and sulfur elements in WAB was conducted through the standard procedure according to ASTM D3176 method [9]. The percentages of Sulphur, nitrogen, hydrogen and carbon were calculated by using vario MAX elementary analyzer. The percentage of oxygen content was determined by subtracting the percentages of hydrogen, sulphur, nitrogen, carbon and ash from hundred percent. The $\mu \mu$ results of CHNS analysis are given in Table 1.

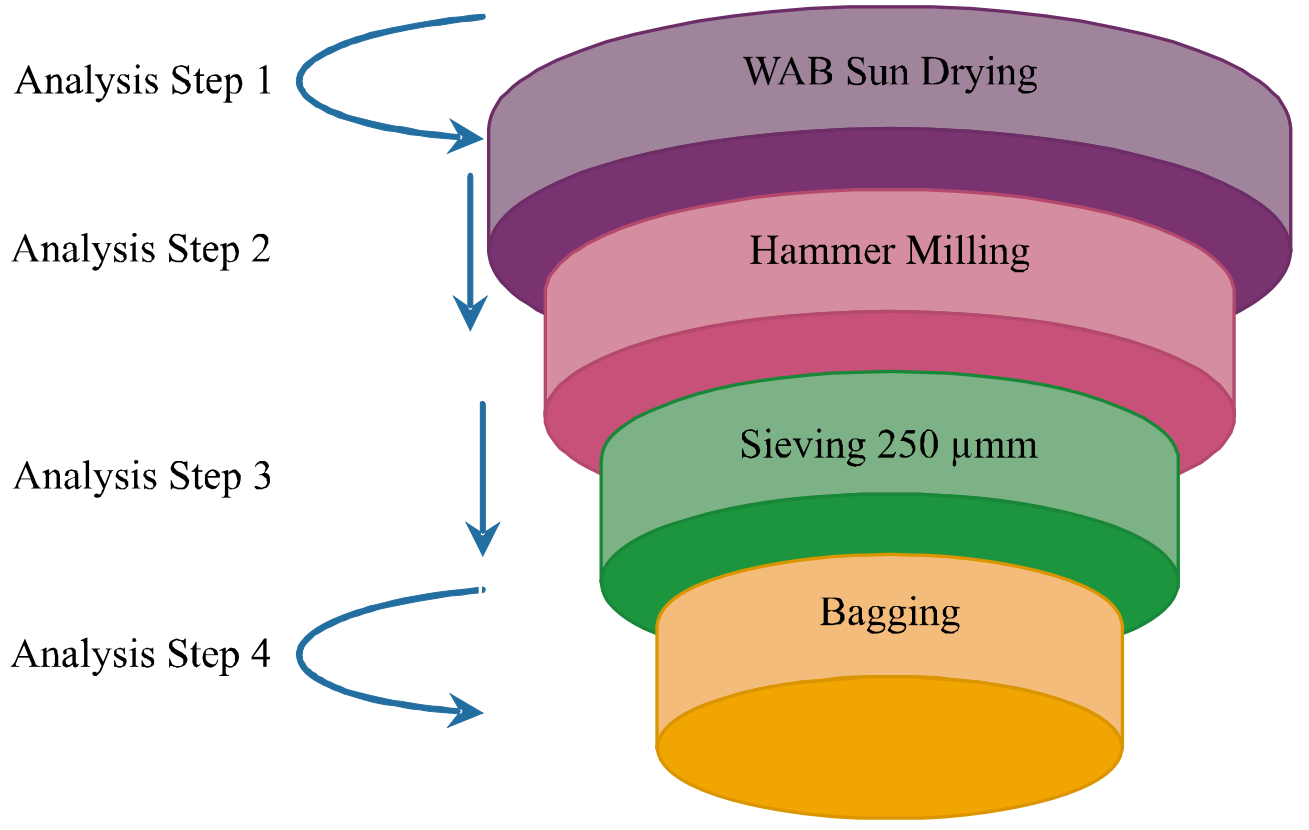

FIG. 1. SYSTEMATIC INVERSE PYRAMID FOR SAMPLE PREPARATION 


\subsection{TGA of Waste Agricultural Biomass}

TGA of WAB materials was determined by using TGA model SDT-Q600 as per ASTM standard method E 113108 . The TGA analysis has been performed in various previous reports by [10-22]. TGA of agricultural residues and other biomass materials to study the kinetic parameters have been widely used technique [10-22]. In this study, thermal characteristics of the RH and CS samples were checked. The TGA study was conducted at $10^{\circ} \mathrm{C} /$ min maintaining the nitrogen and oxygen flow rate of $100 \mathrm{ml} / \mathrm{h}$. The temperature was increased from room temperature to $900^{\circ} \mathrm{C}$. An experimental study was conducted at slow heating rates in order to comprehend the thermal behavior of selected biomasses. According to this method, WAB samples were taken in the range of 15-30 $\mathrm{mg}$ and run in triplicate.

\section{RESULTS AND DISCUSSION}

\subsection{Kinetic Study under $\left(\mathrm{N}_{2}\right)$ Environment}

The thermal behavior of CS and RH samples at a heating rate of $10^{\circ} \mathrm{C} / \mathrm{min}$ under nitrogen environment are presented in Figs. 2-3. The TGA and DTG curves of CS and RH samples elaborate about the mass loss with regard to the temperature and the DTG curves. Certainly, both biomass materials revealed three identical biomass degradation zones during DTG and TGA of samples. In the first zone of TGA and DTG analysis of samples, the mass loss was because of the moisture evaporation followed by hemicellulose, cellulose degradation and in the third and last zone, decomposition was because of the lignin degradation [12]. In the first zone, reduction in mass was because of the moisture evaporation and volatile release observed in thetemperature $22-155^{\circ} \mathrm{C}$ for cotton stalks and from $24-201^{\circ} \mathrm{C}$ for $\mathrm{RH}$ samples respectively. Whereas the devolatillzation which is the main pyrolysis stage of mass loss was observed in temperature range from $155-449^{\circ} \mathrm{C}$ for $\mathrm{CS}$ and for $\mathrm{RH}$ it was observed from $201-560^{\circ} \mathrm{C}$, while the third stage of mass loss ranged from temperature from $449-900^{\circ} \mathrm{C}$ for $\mathrm{CS}$ and for RH samples was in temperature range of 560$900^{\circ} \mathrm{C}$.

The degradation profiles of CS samples were initiated at a lower temperature when compared with $\mathrm{RH}$ degradation profile. Besides, that degradation of CS samples ended at a lower temperature when compared with RH samples.

TABLE 1. THE ULTIMATE AND PROXIMATE ANALYSIS OF RH AND CS

\begin{tabular}{|c|c|c|c|c|c|c|c|c|c|c|}
\hline \multirow[b]{2}{*}{$\begin{array}{l}\text { Biomass } \\
\text { Type }\end{array}$} & \multirow[b]{2}{*}{ References } & \multicolumn{3}{|c|}{ Proximate Analysis } & \multicolumn{4}{|c|}{ Ultimate Analysis } & \multirow{2}{*}{$\begin{array}{c}\text { Bulk } \\
\text { Density } \\
\left(\mathrm{kg} / \mathrm{m}^{3}\right)\end{array}$} & \multirow{2}{*}{$\begin{array}{c}\text { Higher } \\
\text { Heating } \\
\text { Value } \\
(\mathrm{MJ} / \mathrm{kg})\end{array}$} \\
\hline & & $\begin{array}{c}\text { Volatile } \\
\text { Matter } \\
(\%)\end{array}$ & $\begin{array}{c}\text { Fixed } \\
\text { Carbon (\%) }\end{array}$ & $\begin{array}{l}\text { Ash } \\
(\%)\end{array}$ & $\begin{array}{c}\text { Carbon } \\
(\%)\end{array}$ & $\begin{array}{c}\text { Hydrogen } \\
(\%)\end{array}$ & $\begin{array}{c}\text { Oxygen } \\
(\%)\end{array}$ & $\begin{array}{c}\text { Nitrogen } \\
(\%)\end{array}$ & & \\
\hline $\mathrm{RH}$ & This study & 65.39 & 8.96 & 18.55 & 34.33 & 5.36 & 59.43 & 0.29 & 161 & 15.36 \\
\hline $\mathrm{CS}$ & This study & 69.98 & 16.31 & 8.13 & 41.73 & 5.82 & 52.05 & 0.10 & 335 & 16.81 \\
\hline $\mathrm{RH}$ & {$[23]$} & 61.81 & 16.95 & 21.24 & 38.50 & 5.20 & 34.61 & 0.45 & - & 14.69 \\
\hline $\begin{array}{c}\text { Olive } \\
\text { Kernel A }\end{array}$ & {$[24]$} & 72.64 & 24.78 & 2.58 & 51.19 & 6.06 & 39.32 & 0.76 & - & 18.90 \\
\hline Rapeseed & [25] & 70 & 15.8 & 5.8 & 41.1 & 6.0 & 47.8 & 5.1 & - & 19.40 \\
\hline $\begin{array}{l}\text { Wheat } \\
\text { Straw }\end{array}$ & {$[23]$} & 82.12 & 10.98 & 6.90 & 42.95 & 5.35 & 46.99 & 0 & - & 17.98 \\
\hline $\begin{array}{c}\text { Sugarcane } \\
\text { Bagasse }\end{array}$ & [13] & 76.1 & 13.3 & 5.2 & 43.79 & 5.96 & 43.36 & 1.69 & 140 & 17.7 \\
\hline $\begin{array}{c}\text { Sugarcane } \\
\text { Bagasse }\end{array}$ & [23] & 83.66 & 13.15 & 3.20 & 45.48 & 5.96 & 45.21 & 0.15 & - & 18.73 \\
\hline Shea Meal & {$[13]$} & 61.81 & 28.7 & 5.0 & 48.56 & 5.86 & 37.70 & 2.88 & 490 & 19.8 \\
\hline
\end{tabular}


The CS samples revealed higher peak than RH samples under both inert and oxidative atmospheres. The residual weight percent of the CS and RH samples was 13 and 29\% respectively.
The DTG curves of both materials RH and CS revealed dissimilar behavior under an inert environment. The DTG curve generated regarding CS degradation profile and RH degradation profile have shown a varying reduction

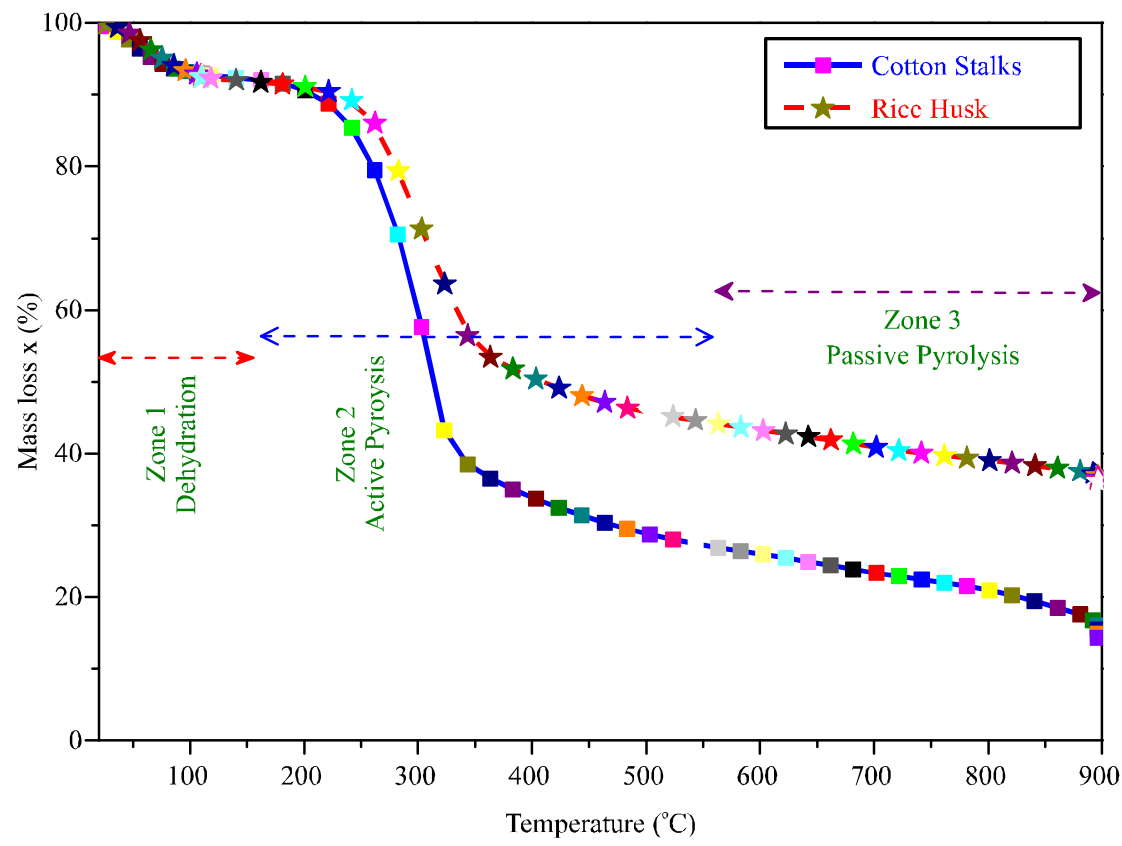

FIG. 2. TGA CURVES OF COTTON STALKS AND RICE HUSK SAMPLES UNDER NITROGEN ENVIRONMENT

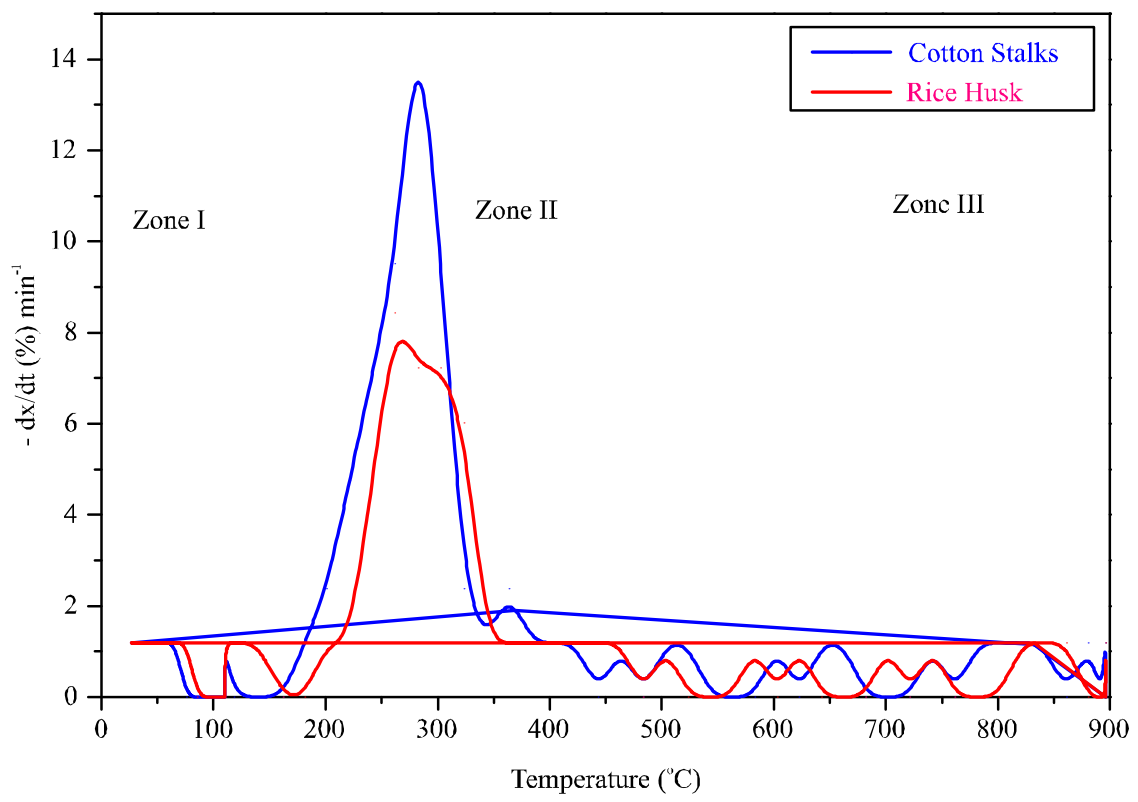

FIG. 3. DTG CURVE OF COTTON STALKS AND RICE HUSK SAMPLES UNDER NITROGEN ENVIRONMENT

Mehran University Research Journal of Engineering \& Technology, Volume 37, No. 2, April, 2018 [p-ISSN: 0254-7821, e-ISSN: 2413-7219] 
trend in mass loss. These dissimilarities in initial decomposition temperatures are due to the difference in elemental and chemical composition biomasses [26]. The main degradation stages of both biomasses ended at $449^{\circ} \mathrm{C}$ for $\mathrm{CS}$ and nearly $560^{\circ} \mathrm{C}$ for $\mathrm{RH}$ samples as shown in Fig. 3. During the pyrolysis of samples, the two different areas of DTG curve were observed. The first region appeared with a more or less prominent shoulder at nearly 197 and $220^{\circ} \mathrm{C}$ for the sample sequence. Whereas the subsequent second region was followed by the peaks maxima at 260 and $285^{\circ} \mathrm{C}$ for above sample sequence. The appearance of the shoulder in DTG curve may be due to the degradation of the hemicellulose and lignin. Whereas the generated DTG peak relates to the degradation of cellulose and lignin. However, when cellulose and hemicellulose degradation overlap, at that point the shoulder generated marks the peak of the hemicellulose degradation [11]. Next, to the end of the second degradation stage, a continuous slow degradation of selected biomasses was observed that may correspond to the slow decomposition of lignin. Table 2 summarizes the TGA and DTG curve characteristics. The reactivity RM is directly proportional to the maximum weight loss $\mathrm{RDTG}_{\max }$ and inversely proportional to the value of its corresponding temperature $\mathrm{TDTG}_{\max }$. The reactivity of samples was calculated by the method adopted in previous studied performed by $[13,17,27]$.

$$
\mathrm{RM}=100 \sum \frac{\mathrm{RDTG}_{\max }}{\mathrm{TDTG}_{\max }}
$$

RM shows the reactivity $\left(\% \mathrm{~s}^{-1} \mathrm{C}-1\right), \mathrm{RDTG}_{\max }$ represents maximum reduction $\left(\% \mathrm{~s}^{-1}\right)$ and $\mathrm{TDTG}_{\max }$ shows peak temperature $\left({ }^{\circ} \mathrm{C}\right)$.

\subsection{Kinetic Study under $\left(\mathrm{O}_{2}\right)$ Oxygen Environment}

TGA curve of RH and CS samples under an oxidative environment at a heating rate of $10^{\circ} \mathrm{C} / \mathrm{min}$ have been drawn against temperature in Figs. 4-5. It is obvious from the data obtained that weight loss occurred in major three stages under oxidative environment. The weight loss of both samples occurred at first stage due to the evaporation of moisture, the weight loss at second stage accounts for devolatilization and the weight loss at third and last stage is due to the combustion of char. The weight loss in the first zone was observed from $23^{\circ} \mathrm{C}$ to nearly $145^{\circ} \mathrm{C}$. At this stage of weight loss, evaporation of water and light molecules may have accounted for weight loss. The weight loss of CS and RH at second stage was observed at temperatures between $153-580^{\circ} \mathrm{C}$ and at the third stage of weight loss that ranged from $580-900^{\circ} \mathrm{C}$ was due to the combustion of the sample under oxygen environment. It is estimated that maximum degradation rate occurred at 282 and $365^{\circ} \mathrm{C}$ for $\mathrm{CS}$ and $\mathrm{RH}$ samples respectively. At the end of the third stage of weight loss, the residual mass of CS and RH was found 4.3 and $7.4 \%$ respectively [26]. Moreover, for those feedstocks producing higher amounts of ash during their combustion, attention must be given to set up the ash removal systems before the setting up of the commercial unit.

TABLE 2. KINETIC BEHAVIOR OF TGA EXPERIMENTS UNDER AN INERT ATMOSPHERE

\begin{tabular}{|c|c|c|c|c|c|c|c|}
\hline Sample & $\begin{array}{c}\text { Temperature } \\
\text { Range }\left({ }^{\circ} \mathrm{C}\right)\end{array}$ & $\begin{array}{c}\text { Rshoulder } \\
\left(\% \mathrm{~s}^{-1}\right)\end{array}$ & $\begin{array}{c}\text { Tshulder } \\
\left({ }^{\circ} \mathrm{C}\right)\end{array}$ & $\begin{array}{c}\text { Rpeak } \\
\left(\% \mathrm{~s}^{-1}\right)\end{array}$ & $\begin{array}{c}\text { Tpeak } \\
\left({ }^{\circ} \mathrm{C}\right)\end{array}$ & $\begin{array}{c}\text { RMx10 } \\
\left(\% \mathrm{~s}^{-1} \mathrm{C}^{-1}\right)\end{array}$ & $\begin{array}{c}\text { Residue }(\%) \\
\left(900^{\circ} \mathrm{C}\right)\end{array}$ \\
\hline $\mathrm{CS}$ & $160-452$ & 0.028 & 197 & 0.041 & 260 & 0.21 & 13 \\
\hline $\mathrm{RH}$ & $220-560$ & 0.31 & 220 & 0.083 & 285 & 0.38 & 29 \\
\hline
\end{tabular}


The RM (Reactivity Values) of CS is higher when compared with RH samples under oxy combustion atmosphere. Table 3 shows reactivity of CS and RH along with the reactivity values calculated by different authors. Combustion characteristics such as initial ignition temperatures, burn out temperatures, TGA and DTG curve are generally used to measure relative combustion characteristics of the biomasses [28]. As CS sample showed lower ignition temperature when compared with RH sample ignition temperature. This study is in agreement with the study performed on biomass and coal samples by [29]. Moreover, an ignition index (D) and combustion index (S) of the samples were calculated from the following equations [29].

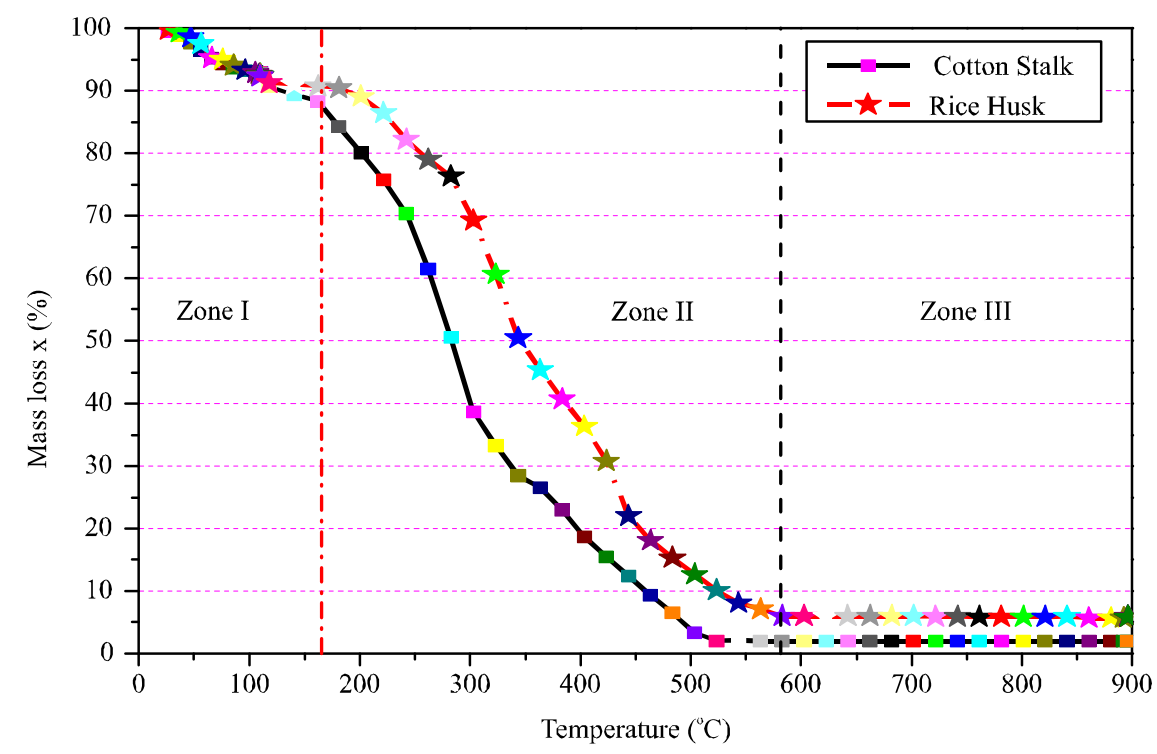

FIG. 4. TGA CURVE OF COTTON STALKS AND RICE HUSK SAMPLES UNDER OXIDATIVE ENVIRONMENT

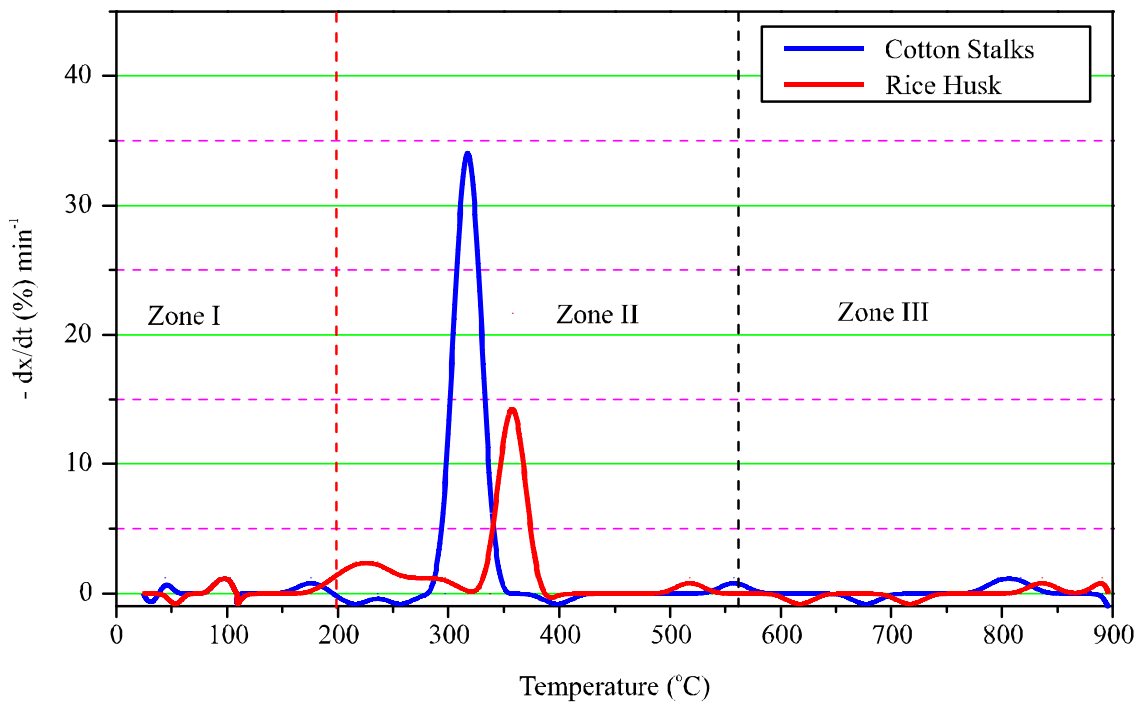

FIG. 5. DTG CURVE OF COTTON STALKS AND RICE HUSK SAMPLES UNDER OXIDATIVE ENVIRONMENT 
$\mathrm{D}=\frac{\mathrm{R}_{\max }}{\left(\mathrm{t}_{\max } \mathrm{t}_{\mathrm{i}}\right)}$

$S=\frac{R_{\max } R_{a}}{\left(T_{i}^{2} T_{b}\right)}$

Here, $t_{\max }$ shows a maximum rate of combustion $t_{\text {i }}$ represents ignition temperature. $\mathrm{R}_{\max }$ is the maximum reduction in mass. $R_{a}$ represents the maximum reduction in mass under oxygen environment. The results of both samples are given in Table 4. It is obvious from the results that with the rise in ignition index (D) value, the ignition performance of biomass materials increases. Besides that, an enhanced burning reactivity may be given to the material showing the higher value of combustion index (S). The CS is more reactive material than RH. The apparent activation energy and order of reaction is shown in Table 5.

\subsection{Kinetics of Waste Agricultural Biomass}

The kinetic investigation has been done by using thermal analysis techniques in order to calculate the kinetic characteristics of biomass [30]. Numerous methods and approaches have been adopted to investigate the thermal behavior of different biomass materials using TGA. In this paper, investigation of kinetic parameters under inert and oxidative environments is calculated by using Arrhenius equation.

$\mathrm{S}=\frac{\mathrm{dx}}{\mathrm{dt}} \mathrm{kx}^{\mathrm{n}}$

Where $\mathrm{x}$ shows conversion ratio and is represented as $\mathrm{x}=\left(\frac{\mathrm{mo}-\mathrm{m}}{\mathrm{mo}-\mathrm{mf}}\right)$, m represents mass of sample at any time whereas 0 and $f$ represent initial and final mass of samples at the end of the stage respectively. $\mathrm{N}$ and $\mathrm{k}$ are reaction order and reaction constants respectively. After combining the Equation (5), the combined Equations (45) becomes linear form Equation (6) represented as:

TABLE 3. KINETIC BEHAVIOR OF TGA EXPERIMENTS UNDER OXIDATIVE ENVIRONMENT

\begin{tabular}{|c|c|c|c|c|c|c|c|c|}
\hline \multirow[b]{2}{*}{ Biomass } & \multicolumn{3}{|c|}{ DE Volatilization Zone } & \multicolumn{3}{|c|}{ Char Combustion } & \multirow{2}{*}{$\begin{array}{l}\text { Ash (\%) } \\
\left(900^{\circ} \mathrm{C}\right)\end{array}$} & \multirow[b]{2}{*}{$\begin{array}{c}\mathrm{RMx} 10^{3} \\
\left(\% \mathrm{~s} \mathrm{~s}^{-1}{ }^{\circ} \mathrm{C}^{-1}\right)\end{array}$} \\
\hline & $\begin{array}{l}\text { Temperature } \\
\text { Range }\left({ }^{\circ} \mathrm{C}\right)\end{array}$ & $\begin{array}{l}\text { Rpeak } \\
\left(\% \mathrm{~s}^{-1}\right)\end{array}$ & $\begin{array}{c}\text { Tpeak } \\
\left({ }^{\circ} \mathrm{C}\right)\end{array}$ & $\begin{array}{c}\text { Temperature } \\
\text { Range } \\
\left({ }^{\circ} \mathrm{C}\right) \\
\end{array}$ & $\begin{array}{l}\text { Rpeak } \\
\left(\% \mathrm{~s}^{-1}\right)\end{array}$ & $\begin{array}{c}\text { Tpeak } \\
\left({ }^{\circ} \mathrm{C}\right)\end{array}$ & & \\
\hline $\mathrm{RH}$ & $171-360$ & 0.064 & 365 & $370-580$ & 0.316 & 375 & 7.4 & 0.63 \\
\hline $\mathrm{CS}$ & $153-282$ & 0.056 & 280 & $339-510$ & 0.216 & 344 & 4.3 & 0.46 \\
\hline
\end{tabular}

TABLE 4. COMBUSTION CHARACTERISTICS OF SAMPLES UNDER OXIDATIVE ENVIRONMENT

\begin{tabular}{|c|c|c|c|c|c|c|c|c|c|}
\hline Sample & $\mathrm{T}_{\mathrm{i}}$ & $\mathrm{T}_{\mathrm{i}}(\mathrm{s})$ & $\begin{array}{c}\mathrm{R}^{\mathrm{a}} \\
\left(10^{-2} \% \mathrm{~s}^{-1}\right)\end{array}$ & $\begin{array}{c}\mathrm{Rmax} \\
\left(\% \mathrm{~s}^{-1}\right)\end{array}$ & $\begin{array}{c}\mathrm{Tmax} \\
(\mathrm{s})\end{array}$ & $\begin{array}{c}\mathrm{Tb} \\
\left({ }^{\circ} \mathrm{C}\right)\end{array}$ & $\mathrm{Tb}(\mathrm{s})$ & $\mathrm{Dx} 10^{7}$ & $\mathrm{Sx}^{10}$ \\
\hline $\mathrm{RH}$ & 230 & 2622 & 0.832 & 0.236 & 4631 & 413 & 2622 & 0.22 & 1.20 \\
\hline $\mathrm{CS}$ & 223 & 2516 & 0.91 & 0.339 & 4516 & 408 & 2516 & 0.36 & 1.50 \\
\hline
\end{tabular}

TABLE 5. APPARENT ACTIVATION ENERGY AND ORDER OF REACTION UNDER INERT AND OXY COMBUSTION ATMOSPHERES

\begin{tabular}{|c|c|c|c|c|c|c|}
\hline \multirow{2}{*}{ Biomass } & \multicolumn{3}{|c|}{ Pyrolysis } & \multicolumn{3}{c|}{ Oxy Combustion } \\
\cline { 2 - 7 } & $\begin{array}{c}\mathrm{E} \\
\left(\mathrm{kJmol}^{-1}\right)\end{array}$ & $\begin{array}{c}\text { Regression } \\
\left(\mathrm{R}^{2}\right)\end{array}$ & $\begin{array}{c}\text { Order of } \\
\text { Reaction } \\
(\mathrm{n})\end{array}$ & $\begin{array}{c}\mathrm{E} \\
\left(\mathrm{kJmol}^{-1}\right)\end{array}$ & $\begin{array}{c}\text { Regression } \\
\left(\mathrm{R}^{2}\right)\end{array}$ & $\begin{array}{c}\text { Order of } \\
\text { Reaction } \\
(\mathrm{n})\end{array}$ \\
\hline $\mathrm{RH}$ & 68.77 & 0.9877 & 0.76 & 118 & 0.998 & 0.94 \\
\hline $\mathrm{CS}$ & 72.31 & 0.973 & 1.15 & 106 & 0.9988 & 1.04 \\
\hline
\end{tabular}

Mehran University Research Journal of Engineering \& Technology, Volume 37, No. 2, April, 2018 [p-ISSN: 0254-7821, e-ISSN: 2413-7219] 
$\mathrm{k}=\operatorname{Aexp}\left(-\frac{\mathrm{E}}{\mathrm{RT}}\right)$

$\ln \left[\frac{-1}{\mathrm{mo}-\mathrm{mf}} \frac{\mathrm{dm}}{\mathrm{dt}}\right]=\ln (\mathrm{A})-\left(\frac{\mathrm{E}}{\mathrm{RT}}\right)+\mathrm{nln}\left(\frac{\mathrm{m}-\mathrm{mf}}{\mathrm{mo}-\mathrm{mf}}\right)$

Where $\mathrm{dm} / \mathrm{dt}$ displays the ratio of change in mass with respect to change in time, $\mathrm{R}$ represents the universal gas constant, $\mathrm{A}$ is the pre-exponential factor. Where Equation (7) lead to linear form written as:

$\mathrm{Y}=\mathrm{B}+\mathrm{CX}+\mathrm{D} * \mathrm{Z}$

Where

$y=\ln \left[\frac{-1}{m o-m f} \frac{d m}{d t}\right], x=\frac{1}{T}, z=\ln \left(\frac{m-m f}{m o-m f}\right), B=\ln (A), C=-\frac{E}{R}, D=n$

Here constants B, C and D are calculated by multi-linear regression of the TGA data for each stage using Microsoft Excel. The kinetic results were compared with the data available in the literature. RH samples have the higher values of activation energy $118 \mathrm{~kJ} /$ mole, $\ln \mathrm{A} 19.2 \mathrm{~s}^{-1}$ while CS sample activation energy was $106 \mathrm{~kJ} /$ mole, $\mathrm{ln}$ A18.1 s ${ }^{-1}$ under oxy combustion atmosphere. Dorgeet. al. used the similar experimental and analytical method for Miscanthus. The order of reaction for both samples was observed from 0.76-1.15. A similar order of reaction was found by $[16,21,31]$.

\section{CONCLUSION}

The kinetic study of CS and $\mathrm{RH}$ revealed that in the first zone, reduction in mass was because of the moisture evaporation and volatile release observed in the temperature $22-155^{\circ} \mathrm{C}$ for cotton stalks and from $24-201^{\circ} \mathrm{C}$ for RH samples respectively. Whereas the devolatillzation which is the main pyrolysis stage of mass loss was observed in temperature range from $155-449^{\circ} \mathrm{C}$ for $\mathrm{CS}$ and for RH it was observed from $201-560^{\circ} \mathrm{C}$, while the third stage of mass loss ranged from temperature from 449$900^{\circ} \mathrm{C}$ for $\mathrm{CS}$ and for $\mathrm{RH}$ samples was in temperature range of $560-900^{\circ} \mathrm{C}$. The weight loss under oxidative environment in the first zone was observed from $23^{\circ} \mathrm{C}$ to nearly $145^{\circ} \mathrm{C}$. At this stage of weight loss, evaporation of water and light molecules may have accounted for weight loss. The weight loss of CS and RH at second stage was observed at temperatures between $153-580^{\circ} \mathrm{C}$ and at the third stage of weight loss that ranged from $580-900^{\circ} \mathrm{C}$ was due to the combustion of the sample under oxygen environment. It is estimated that maximum degradation rate occurred at 282 and $365^{\circ} \mathrm{C}$ for $\mathrm{CS}$ and $\mathrm{RH}$ samples respectively. The results reveal that the HHV of RH and CS possess good prospect for thermochemical conversion into value able biofuels. The HHV of RH and CS samples were found 15.36 and $16.81 \mathrm{MJ} / \mathrm{kg}$. The apparent activation energies under pyrolysis were 68.77 and $72.31 \mathrm{kJmol}^{-1}$ under oxy combustion atmosphere 118 and $106 \mathrm{kJmol}^{-1}$ for above sample sequence. The order of reaction (n) and regression coefficient $\left(\mathrm{R}^{2}\right)$ under both atmospheres for both samples were $0.76,1.15,0.9877$ and 0.973 under pyrolysis whereas under oxidative atmosphere $0.94,1.04,0.998$ and 0.9988 respectively. The results collected in this study reveal that the RM of CS samples were higher than RH samples under both nitrogen and oxygen atmospheres. The TGA and DTG curve presented lower degradation temperatures for CS samples than RH samples under both inert and oxidative environments.

\section{ACKNOWLEDGEMENT}

The authors are thankful to Prof. Dr. Muhammad Ishaque Abro, Department of Metallurgy \& Materials Engineering, Mehran University of Engineering \& Technology, Jamshoro, Pakistan, for providing experimental facilities and guidance during performing TGA experiments.

\section{REFERENCES}

[1] Capellán, I., Mediavilla, M., de Castro, C., Carpintero, Ó., and Miguel, L.J., "Fossil Fuel Depletion and Socio Economic Scenarios: An Integrated Approach", Energy, Volume 77, pp. 641-666, 2014.

[2] Channiwala, S.A., and Parikh, P.P., "A Unified Correlation for Estimating HHV of Solid, Liquid and Gaseous Fuels", Fuel, Volume 81, pp. 1051-1063, 2002.

[3] Chen, W.H., and Kuo, P.C., "Isothermal Torrefaction Kinetics of Hemicellulose, Cellulose, Lignin and Xylan Using Thermogravimetric Analysis", Energy, Volume 36, pp. 6451-6460, 2011.

[4] Chouchene, A., Jeguirim, M., Khiari, B., Zagrouba, F., and Trouvé, G., "Thermal Degradation of Olive Solid Waste: Influence of Particle Size and Oxygen Concentration", Resources, Conservation and Recycling, Volume 54, pp. 271-277, 2010. 
[5] Chouchene, A., Jeguirim, M., Trouvé, G., Reguillon, A. and Le, B.G., "Combined Process for the Treatment of Olive Oil Mill Wastewater: Absorption on Sawdust and Combustion of the Impregnated Sawdust", Bioresource Technology, Volume 101, pp. 6962-6971, 2010.

[6] Dorge, S., Jeguirim, M., and Trouvé, G., "Thermal Degradation of Miscanthus Pellets: Kinetics and Aerosols Characterization", Waste and Biomass Valorization, Volume 2, pp. 149-155, 2011.

[7] Gabrielle, B., Bamière, L., Caldes, N., De Cara, S., Decocq, G., Ferchaud, F., Loyce, C., Pelzer, E., Perez, Y., Wohlfahrt, J., and Richard, G., "Paving the Way for Sustainable Bioenergy in Europe: Technological Options and Research Avenues for Large-Scale Biomass Feedstock Supply", Renewable and Sustainable Energy Reviews, Volume 33, pp. 11-25, 2014.

[8] Ghetti, P., Ricca, L., and Angelini, L., "Thermal Analysis of Biomass and Corresponding Pyrolysis Products", Fuel, Volume 75, pp. 565-573, 1996.

[9] Grønli, M.G., Várhegyi, G., and Di, B.C., "Thermogravimetric Analysis and Devolatilization Kinetics of Wood", Industrial \& Engineering Chemistry Research, Volume 41, pp. 4201-4208, 2002.

[10] Haykiri-Acma, H., and Yaman, S., "Thermal Reactivity of Rapeseed (Brassica Napus L.) under Different Gas Atmospheres", Bioresource Technology, Volume 99, pp. 237-242, 2008 .

[11] Höök, M., and Tang, X., "Depletion of Fossil Fuels and Anthropogenic Climate Change - A Review", Energy Policy, Volume 52, pp. 797-809, 2013.

[12] Jeguirim, M., Dorge, S., Loth, A., and Trouvé, G., "Devolatilization Kinetics of Miscanthus Straw from Thermogravimetric Analysis", International Journal of Green Energy, Volume 7,pp. 164-173.

[13] Jeguirim, M., Dorge, S., and Trouvé, G., "Thermogravimetric Analysis and Emission Characteristics of Two Energy Crops in Air Atmosphere: Arundo Donax and Miscanthus Giganthus", Bioresource Technology, Volume 101, pp. 788-793, 2010.

[14] Jeguirim, M., and Trouvé, G., "Pyrolysis Characteristics and Kinetics of Arundo Donax Using Thermogravimetric Analysis", Bioresource Technology, Volume 100, pp. 4026-4031, 2009.

[15] Li, X.G., Ma, B.G., Xu, L., Hu, Z.W., and Wang, X.G., "Thermogravimetric Analysis of the Co-Combustion of the Blends with High Ash Coal and Waste Tyres", Thermochimica Acta, Volume 441, pp. 79-83, 2006.

[16] Liou, T.H., Chang, F.W., and Lo, J.J., "Pyrolysis Kinetics of Acid-Leached Rice Husk", Industrial \& Engineering Chemistry Research, Volume 36, pp. 568-573, 1997.

[17] Liu, H., Jiang, G.M., Zhuang, H.Y., and Wang, K.J., "Distribution, Utilization Structure and Potential of Biomass Resources in Rural China: With Special References of Crop Residues", Renewable and Sustainable Energy Reviews, Volume 12, pp. 1402-1418, 2008.

[18] Mansaray, K., and Ghaly, A., "Thermal Degradation of Rice Husks in Nitrogen Atmosphere",Bioresource Technology, Volume 65, pp. 13-20, 1998.
Masnadi, M.S., Habibi, R., Kopyscinski, J., Hill, J.M., Bi, X., Lim, C.J., Ellis, N., and Grace, J.R., "Fuel Characterization and Co-Pyrolysis Kinetics of Biomass and Fossil Fuels", Fuel, Volume 117, pp. 1204-1214, 2014.

[20] Munir, S., Daood, S.S., Nimmo, W., Cunliffe, A.M., and Gibbs, B.M., "Thermal Analysis and Devolatilization Kinetics of Cotton Stalk, Sugar Cane Bagasse and Shea Meal under Nitrogen and Air Atmospheres", Bioresource Technology, Volume 100, pp. 1413-1418, 2009.

[21] Orfao, J., Antunes, F., and Figueiredo, J., "Pyrolysis Kinetics of Lignocellulosic Materials - Three Independent Reactions Model”, Fuel, Volume 78, pp. 349-358, 1999.

[22] Park, S.W., and Jang, C.H., "Effects of Pyrolysis Temperature on Changes in Fuel Characteristics of Biomass Char", Energy, Volume 39, pp. 187-195, 2012.

[23] Prasertsan, S., and Sajjakulnukit, B., "Biomass and Biogas Energy in Thailand: Potential, Opportunity and Barriers", Renewable Energy, Volume 31, pp. 599-610, 2006.

[24] Shafie, S.M., Mahlia, T.M.I., Masjuki, H.H., and AhmadYazid, A., "A Review on Electricity Generation Based on Biomass Residue in Malaysia", Renewable and Sustainable Energy Reviews, Volume 16, pp. 5879-5889, 2012.

[25] Sulaiman, F., and Abdullah, N., "Optimum Conditions for Maximising Pyrolysis Liquids of Oil Palm Empty Fruit Bunches", Energy, Volume 36, pp. 2352-2359, 2011.

[26] Vamvuka, D., Kakaras, E., Kastanaki, E., and Grammelis, P., "Pyrolysis Characteristics and Kinetics of Biomass Residuals Mixtures with Lignite", Fuel, Volume 82, pp. 1949-1960, 2003.

[27] Vamvuka, D., and Sfakiotakis, S., "Combustion Behaviour of Biomass Fuels and Their Blends with Lignite", Thermochimica Acta, Volume 526, pp. 192-199, 2011.

[28] Verma, V.K., Bram, S., Delattin, F., Laha, P., Vandendael, I., Hubin, A., and De Ruyck, J., "Agro-Pellets for Domestic Heating Boilers: Standard Laboratory and Real Life Performance", Applied Energy, Volume 90, pp. 17-23, 2012.

[29] Vitali, F., Parmigiani, S., Vaccari, M., and Collivignarelli, C., "Agricultural Waste as Household Fuel: TechnoEconomic Assessment of a New Rice-Husk Cookstove for Developing Countries", Waste Management, Volume 33, pp. 2762-2770, 2013.

[30] Wilson, L., Yang, W., Blasiak, W., John, G.R., and Mhilu, C.F., "Thermal Characterization of Tropical Biomass Feedstocks", Energy Conversion and Management, Volume 52, pp. 191-198, 2011.

[31] Yu, Y.H., Kim, S.D., Lee, J.M., and Lee, K.H., "Kinetic Studies of Dehydration, Pyrolysis and Combustion of Paper Sludge", Energy, Volume 27, pp. 457-469, 2002.

[32] Mahar, R.B., Sahito, A.R., and Uqaili, M.A., "Biomethanization Potential of Waste Agricultural Biomass in Pakistan: A Case Study", International Journal of Biomass \& Renewables, Volume 1, pp. 32-37, 2012. 